\title{
Hiring and retaining physicians to work in primary health care in the state of Bahia
}

\author{
Laíse Rezende de Andrade 1 \\ Isabela Cardoso de Matos Pinto 1 \\ Catharina Leite Matos Soares ${ }^{1}$ \\ Vinício Oliveira da Silva ${ }^{2}$ \\ 1 Universidade Federal da Bahia / Instituto de Saúde Coletiva (ISC/UFBA), Salvador / BA - Brazil \\ 2 Universidade Federal do Paraná (UFPR), Matinhos / PR - Brazil
}

This article analyzes the strategies of work management adopted at the Fundação Estatal Saúde da Família (State Health Family Foundation) (FESF-SUS), which was created to hire and allocate physicians in the Brazilian state of Bahia. The research aims to contribute to the debate about the difficulties of hiring and retaining physicians to work in the public policy promoting family health "Estratégia Saúde da Família" (ESF). The research consisted of a case study adopting several methodological strategies, with emphasis on documentary analysis. The findings show that one solution to hire and retain physicians is the creation of an inter-municipal career. The proposed work management of the Foundation included aspects such as variable compensation, worker mobility between municipalities, and factors associated with the provision of physicians to work in public health. The complexity of this proposal is faced with the lack of experience in operating this form of work management, as well as with the structural and institutional issues that historically marked the work management in the municipalities.

Keywords: public administration; health care; family health strategy; human resources for health; unified health system.

\section{Provimento e fixação de médicos na atenção primária à saúde no estado da Bahia}

Este artigo analisa as estratégias de gestão do trabalho da Fundação Estatal Saúde da Família (FESF-SUS), criada para suprir a necessidade de médicos no Estado da Bahia. Objetiva contribuir com o debate acerca das dificuldades de provimento e fixação de médicos na Estratégia Saúde da Família (ESF). A pesquisa consistiu em um estudo de caso, por meio de diversas estratégias metodológicas, destacando-se a análise documental. Os achados apontam como solução a criação de uma carreira intermunicipal. A proposta de gestão do trabalho da Fundação Estatal Saúde da Família (FESF-SUS, n.d.) incluiu os seguintes aspectos: remuneração variável, mobilidade do trabalhador entre os municípios e fatores associados ao suprimento de médicos. A complexidade dessa proposta se depara com a ausência de experiência na gestão desse modelo e também com as questões estruturais e institucionais que marcaram historicamente a gestão do trabalho nos municípios.

Palavras-chave: administração pública; atenção à saúde; estratégia saúde da família; recursos humanos em saúde; sistema único de saúde.

\section{Provisión y mantenimiento de médicos de atención primaria de salud en el estado de Bahía}

El artículo analiza las estrategias de gestión del trabajo de la Fundación Estatal de Salud Familiar (FESF-SUS), creada para satisfacer la necesidad de los médicos en el estado de Bahía. Tiene como objetivo contribuir al debate sobre las dificultades en el suministro y mantenimiento de los médicos en el programa Estrategia Salud de la Familia. La investigación consistió en un estudio de caso mediante diversas estrategias metodológicas, entre las que se destaca el análisis documental. Los resultados apuntan como solución la creación de una carrera intermunicipal. La propuesta de gestión del trabajo de la Fundación Estatal Salud de Familia (FESF-SUS, n.d.) incluye aspectos tales como compensación variable, movilidad de los trabajadores entre los municipios y factores asociados con el suministro de los médicos. La complejidad de esta propuesta se depara con la falta de experiencia en el manejo de este modelo y también con las cuestiones estructurales e institucionales que históricamente han marcado la gestión del trabajo en los municipios. Palabras clave: administración pública; atención a la salud; estrategia de salud familiar; recursos humanos en salud; sistema único de salud. 


\section{INTRODUCTION}

Retaining health professionals in primary healthcare is not an issue that is unique to Brazil (Collar, Almeida, \& Ferla, 2015; Oliveira et al., 2015; Scheffer, 2015a). This matter is in the agenda of various countries worldwide as inducing measures in order to fulfill the requirements of doctors in the socalled "public health gaps" (regional Medical Board for the State of São Paulo [Cremesp], 2013a, 2013b; Santos, Costa, \& Girardi, 2015; R. P. Silveira \& Pinheiro, 2014; Wilson et al., 2009).

Analyses on international experiences (Oliveira et al., 2015) in the provision and retention of professionals in areas of high social vulnerability comprise a wide range of strategies, from incentives to compulsory requirement, such as selection, education, mandatory civil service, regulation, incentives and support (Rourke, 2010). A large part of these strategies corresponds to the recommendations prepared by the World Health Organization (WHO) to improve the retention of health workers in rural and remote areas (Brazilian Center for Health Studies [Cebes], 2016). The shortage of health professionals in remote and vulnerable areas is a key obstacle for the universalization of access to health in various countries and health systems around the world (Oliveira et al., 2015; Wilson et al., 2009).

Studies performed in the scope of the Brazilian National Health System (SUS) reiterate this problem in Brazil, especially in relation to doctors, emphasizing the difficulties of hiring these medical professionals, in certain specialties, for municipalities of the interior and outskirts of large urban centers (F. C. Carvalho, 2014; M. S. Carvalho \& Sousa, 2013; Cremesp, 2013a, 2013b; R. P. Silveira \& Pinheiro, 2014). In primary healthcare, these issues escalate due to the difficulty in providing and retaining health professionals in areas of risk and of difficult access, generating concentrations in large urban centers, as well as the high turnover of these professionals, due to various factors, such as the precariousness ${ }^{1}$ of labor relations, poor working conditions and low assessment of this level of attention (C. V. A. Campos \& Malik, 2008; F. E. Campos, Machado, \& Girardi, 2009; Escorel, Giovanella, Mendonça, \& Senna, 2007).

The Federal State of Brazil has been tackling this matter since 1976, implementing programs for the internalization of health professionals, mainly doctors, such as the Internalization of Health and Sanitation Action Program (PIASS - 1976), Internalization of the Brazilian National Health System (PISUS - 1993), Internalization of the Work in Health Program (PITS - 2001) and, more recently, the Primary Care Professional Appreciation Program (Provab - 2011) (Cremesp, 2013a, 2013b; Girardi et al., 2011; Machado, 1997) and the "Mais Médicos" Program (PMM) (Inter-ministerial Ordinance 1369, 2013).

The State Family Health Foundation (FESF-SUS) was created as a proposal for the legaladministrative solution of the policy of providing and retaining workers in the Family Health Strategy (ESF) in the state of Bahia. Such initiative was established as an alternative for an inter-federative public career in health, with the aim of attracting the hiring and partnerships of municipal and state administrators, as well as workers, namely doctors, through a policy of an administration of the work with an inter-municipal scope (State Family Health Foundation [FESF-SUS], n.d.).

\footnotetext{
${ }^{1}$ The notion of precarious work, assumed in this article, is equivalent with the concept used by the Brazilian Council of State and Municipal Health Departments (CONASS and CONASEMS), namely: precarious work is related to employment relations in SUS that do not guarantee labor and social security rights, established by law, either through direct or indirect labor relations. It is established that even in indirect labor relations it is necessary to guarantee the selection process and, above all, a democratic relationship with the workers (Brazilian Council of Health Departments [CONASS], 2004).
} 
This policy was presented by FESF-SUS as an innovation in healthcare, in the measure in which it aimed to improve existing experiences and create positive opportunities for attending to the need of incorporating practices that convey the principles of integrality, universality and equity in the scope of the SUS. This policy is based on the understanding that administration, organization of the health services, health workers and healthcare users are all important actors in the process of the construction of innovative practices in health management and care (Ceccim et al., 2016).

That having been said, this article has the purpose of analyzing the policy for providing and retaining ${ }^{2}$ medical professionals, developed by FESF-SUS in the State of Bahia.

\section{THEORETICAL-METHODOLOGICAL PROCEDURES}

A unique case study (Yin, 2001), developed in the Health Department for the State of Bahia (Sesab), which had as objective addressing the issue of providing and retaining medical professionals in primary healthcare of state, which resulted in the Labor Management Policy, developed by FESF-SUS. Kingdon's (2003) theory of public policy cycle was used as reference, where the author emphasized the need for differentiating the active participants, the contributions of each of the actors and the dynamics comprising three dimensions of analysis: a) recognition of the problem; b) formulation of proposals/alternatives for the solution to the problems; and c) setting-up of the political negotiation process in relation to the proposal.

This frame of reference permitted the identification of the institutional actors responsible for the process of formulating the proposal, the opposing parties, the supporters and the entrepreneurs, who defend the proposal. The latter do not permit the process to be without control. They introduce their ideas in various forums and try to soften the political communities who usually resist to great changes. The survival of the ideas depends on some aspects: political leadership; technical possibility guaranteeing the implementation phases; elimination of inconsistencies; consensus (awareness of the problem and agreement on the proposed solutions). In this regard, the figure of the entrepreneur is very important, in other words, the person who assumes the defense of the proposal and seeks for support, co-opting adhesions to the FESF-SUS proposal for provision and retention.

Regarding the process in which the proposal was submitted, it was possible to identify the problems and the solutions presented for the shortage of health professionals in the municipalities of the state of Bahia, as well as the political negotiation process.

The strategies used for data collection were: documental analysis; semi-structured interviews with key-informants, as well as the use of data produced by a research commissioned to the Federal University of Minas Gerais (UFMG) by Sesab, with the purpose of characterizing the primary healthcare management; family health management and the administration of the workers of the ESF in the state of Bahia, cross-checked with other documents and data of the SUS information system, whereby interviews were carried out with coordinators of primary healthcare of the municipalities of Bahia, corresponding to $51.3 \%$ of the primary healthcare managers of the mentioned state.

\footnotetext{
${ }^{2}$ It should be observed that in human resources literature it is possible to find the use of the terms fixating and retaining as having the same meaning. In this article, the mentioned terms and the word permanenceare all used to designate the same idea (Perpetuo, Oliveira, \& Ribeiro, 2009).
} 
For documental analysis official national and state documents were used related to the establishment of FESF-SUS, such as ordinances, technical notes, texts, publications and minutes of meetings of the Ministry of Planning, Ministry of Health (MS) and Sesab.

Semi-structured interviews were performed with the following key-actors: Director of the Primary Healthcare of Sesab; representative of the Attorney-General for the state of Bahia; state of Bahia Public Prosecutor; State of Bahia Health Council; and Council of Municipal Health Departments (COSEMS) of Bahia.

The material produced from the interviews was transcribed, processed in matrixes and submitted to the Bardin thematic content analysis (1977), observing the key-words and data related to the matter, based on the Kingdon (2003) analytical categories.

\section{RESULTS}

\subsection{Formulation Process of the FESF-SUS Labor Management Policy}

In 2007, the political context was fundamental for the advent of an alternative for the issue of retaining medical professionals in areas of difficult access in the state of Bahia. It was the formulation of the Career, Employment and Salaries Plan (PECS), as well as structuring inter-municipal careers for primary healthcare in Bahia, one of the outcomes of the creation of FESF-SUS, established through the approval of laws in 69 municipalities of Bahia. In the mentioned year, a new government started in Bahia, opening a "window of opportunities" for debate related to new legal-administrative models. An ex-manager of the MS took over Sesab gather discussion on alternative models for hospital management in the country, appointing director of the primary healthcare for the state of Bahia a general practitioner, ex-consultant of the MS. In the mentioned institutional context, Sesab together with the 417 municipalities was facing difficulties in providing doctors, resulting in the ESF having the lowest coverage in the Northeast (State of Bahia, n.d.).

The construction of the FESF-SUS proposal represented a complex process, due to the magnitude of the problems involved, the magnitude of its objectives, its innovative character and the diversity of political actors involved (Andrade, Teixeira, \& Machado, 2012).

In relation to the active participants of the formulation and implementation process of the proposal, there was the leadership of the primary healthcare director who, according to the adopted referential, exercised the role of political entrepreneur, with the support of the state secretary and favorable analysis on the part of state prosecutors. With reference to the collective actors, COSEMS, the State Council of Health (CES) and the Bipartite Interagency Commission (CIB) of Bahia participated in the process.

\subsection{Issues to be addressed: situation of the primary healthcare in the state of Bahia}

In 2009, the population of Bahia, in accordance with IBGE (Brazilian Institute of Geography and Statistics), was of 12,160,445 inhabitants, distributed unequally in the 417 municipalities and concentrated in the larger municipalities. Up until today, the smaller municipalities present more difficult access, a population frequently in a worse social and economic situation and with lower fiscal capacity (Scheffer, 2015a). Over half of the municipalities of Bahia have up to 20,000 inhabitants. Out of the remaining 
municipalities, 145 concentrate between 20,000 and 100,000 inhabitants, and only 18 municipalities have more than 100 thousand inhabitants. Furthermore, the implementation of the ESF is overdue, reaching in 2008 only $50 \%$ of its coverage, the lowest average in the whole Northeast (Andrade, 2011).

In respect to the proportion of doctors per inhabitant, while in Brazil this proportion was of 2-11, in Bahia it was of 1-25 doctors for every 1,000 inhabitants in 2015. Specifically in relation to family doctors, of this total amount presented only 0.95 in Brazil and 0.36\% in Bahia, respectively (Scheffer, 2015a).

The diagnosis of the ESF of Bahia pointed out insufficient infrastructure and inputs, difficulties in hiring professionals, in view of the existence of a competitive market among the municipalities and, as a consequence, a high turnover of professionals; instability of the teams and precariousness of labor relations, imposed by the absence of a career guaranteeing the labor rights and that considered the specificities of the work in Family Health. In addition, there were reduced investments in permanent education and low quality healthcare, resulting in the dissatisfaction of users and low standards of problem-solving, having, also, situations of irregularity before organisms such as Court of Auditors, Public Ministry, Controller General of the State and of the MS (Andrade, 2011).

Most of the responding municipalities hired doctors directly, in other words, without the intermediation of organizations such as cooperatives, Social Organizations (O.S.), Civil Society Organization for Public Interest (OSCIP). Nevertheless, temporary appointments corresponded to $97 \%$, generating insecurity of the workers and managers in relation to the permanence of the doctors, dissatisfaction of users and, on the other hand, some "benefits" such as housing, transport and shifts in municipal hospitals (Andrade, 2011).

This scenario weakens collective negotiations, in the face of the diversity of contracts signed, established in a large number of municipalities between workers and public administrators. The differences in the amounts paid to the doctors with temporary contracts also drew attention, reaching almost the double of the salary of civil servants. The average permanence of the medical professionals in the municipalities varied between 1 to 2 years, according to a research carried out by UFMG. A reduced number of municipalities - approximately $5 \%$ of those investigated - claimed not to have turnovers in their municipalities (Andrade, 2011). An investigation was made with the managers in relation to the factors they considered as being most important for reverting this panorama (Table 1).

\section{TABLE 1 FACTORS THAT MANAGERS CONSIDERED AS BEING MOST IMPORTANT FOR RETAINING DOCTORS IN THE FAMILY HEALTH STRATEGY}

\begin{tabular}{cc} 
Factors & (\%) \\
Remuneration & $86 \%$ \\
Good conditions and good working environment & $42.5 \%$ \\
Labor relations such as social security protection & $38.8 \%$ \\
Availability of instruments and equipment & $32.7 \%$ \\
Offer of qualification & $28 \%$ \\
\hline
\end{tabular}




$\begin{array}{cc}\text { Factors } & \text { (\%) } \\ \text { Other work opportunities } & 25.7 \% \\ \text { Access to preparatory resources } & 25.2 \% \\ \text { Reference to specialized therapeutic care } & 24.3 \% \\ \text { Possibility of discussion of cases } & 22.4 \% \\ \text { Access to education for children } & 19.6 \% \\ \text { Work for partner } & 12.6 \% \\ \text { Opportunities of leisure and culture } & 11.7 \%\end{array}$

Source: Elaborated by the authors.

It is important to observe that the factors that attract and retain these professionals are not always equivalent. Remuneration, for example, is a factor with the potential for attracting and retaining, as well as the existence of labor relations and opportunities for other concomitant jobs. On the other hand, good working conditions, possibility of referral to specialized care and access to qualification present a higher potential of retaining than of attraction.

Remuneration has a prominent place in the answers of the managers, nevertheless, it is observed that the breakdown of the financing and the quantity of resources has not been sufficient to retain these workers and, often, not sufficient for hiring workers for the ESF.

\subsection{Alternative solutions and the negotiation process between governmental -and non-governmental actors: constructing a career for SUS in Bahia}

In order to address the issue presented in primary healthcare of Bahia, in 2007, the preparation of an inter-federative legal-administrative alternative was started, linked to the indirect administration of the municipalities. The main objective was to provide and retain workers in the ESF, though adhesion of the municipalities, with the aim of producing an inter-municipal network for the organization of the healthcare and administration of the work in the ESF, including an effort of regulating this market. In 2009, the legal entity proposed was the FESF-SUS.

There was a certain resistance by some members of the CES - such as representations of the labor unions, who saw the proposal as outsourcing - and support of Council of Municipal Health Departments (COSEMS) in the negotiation process.The proposal was approved by CIB and CES, and FESF-SUS was established, in an inter-municipal manner, by 69 municipalities. Other municipal managers, who maintained doubts on the possible incurrence of the Fiscal Responsibility Law (LRF) on the hiring, as well uncertainties on possible incentives of the MS and Sesab, opted for no adhering to the proposal at present. It should be observed that other actors - Civil Cabinet, Public Ministry and State AttorneyGeneral - participated in the negotiation process for the establishment of FESF-SUS (Andrade, 2011).

- It should be highlighted that the main objective of the creation of FESF-SUS was to provide and retain workers through the improvement of the working conditions in the state, in an action allied to the qualification of management and of healthcare, articulating work and education in health. There 
was also the proposal of assessing the attainment of targets, instituting a variable remuneration in accordance to these targets. With this purpose a policy for the administration of the work was created contemplating permanent education, admission of workers through public tenders and a PECS.

\section{a) Guidelines of the management proposal of the work for the provision and retainment of ESF professionals}

The FESF-SUS PECS took the following elements for its guidelines: a) define a broader range of functional evolution, with time frame suitable for FESF-SUS and to the functional life of the employees; b) contemplate the specificities of the services and increase the possibilities of assignment and mobility of doctors in the organizational units of FESF-SUS; c) make salary ranges of FESF-SUS compatible with the local/regional market; d) establish a policy of admission, functional integration, evolution, development and performance assessment; e) make the doctors responsible for their own evolution, establishing processes to optimize their professional development (FESF-SUS, n.d.).

\section{b) Selection and recruitment procedures of doctors for ESF}

The admission of the employee should occur through public tender, in accordance with the demands of the management contracts established between FESF-SUS and the contracting municipalities. The number of doctors shall be defined by the municipalities and, from the time of signing up for the tender, the doctor should have access to the characteristics of each municipality, with the aim of stimulating the choice, from aspects that favor the permanence of the doctor.

The recruitment procedure selected was via the CLT (Brazilian Consolidated Labor Laws), with the aim of assuring labor and social security rights. Nevertheless, the definition of the CLT regimen brought about costs that usually the municipalities cannot or do not wish to assume on their contracting processes. Such situation of contractual insecurity was guaranteeing an "economy" for the municipal managers, once it did not assure labor and social security rights. On the other hand, it "benefitted" the doctor, who received a higher salary for working in accordance with this logic. With the CLT procedure of FESF-SUS, municipal managers were obliged to recalculate due to the additional costs.

The operationalization of the inter-federal and collegiate design was a challenge for FESF-SUS and for the municipalities, a proposal without precedence in the history of SUS and in the legislation of the country, despite Brazil traditionally having an inter-federal relation among its members. Thus, to build a cooperative management permitting the mobility of doctors among the municipalities, throughout their career, would be one of the most attractive elements for doctors, but could also be the cause of disputes between the contracting municipalities and FESF-SUS.

\section{c) Compensation ranges}

FESF-SUS defined eleven compensation ranges. The criteria used for such definition were Social Development Index combined with the Economic Development Index, both of the state government, associated to the salaries presented in the ESF labor market research performed by UFMG. The municipalities that adhered to FESF-SUS were distributed among the compensation ranges in accordance with the criteria related to socio-economic differences and the conditions for the provision and retainment of doctors among the municipalities and regions of the state of Bahia. 
The zero range corresponded to an index of a very high shortage of professionals, low socio-economic indexes, having the greatest difficulties in the provision and retainment of doctors. Range 10 is on the opposite pole, municipalities with more attractive conditions, such as schools, leisure, good roads, etc. From this difference in the potential of retaining professionals, municipalities of different ranges would pay different gratifications to the doctors. In order to be feasible, it is foreseen that the municipalities located in the zero-to-four ranges would have subsidies from incentives of the MS and Sesab.

Moreover, this compensation composition based on targets and commitments, with the purpose of motivating the worker to care with quality, brought along the challenge of creating an information system capable of operating this complexity, permitting managers to qualified in FESF-SUS and in the municipalities to also be able to operate the information system. After all, poor management of these processes could lead to labor contingencies and generate losses that could impair the contracts and FESF-SUS itself.

\section{d) Breakdown of the compensation for workers of FESF-SUS}

The remuneration proposal of doctors included fixed and variable components (Andrade, 2011). The fixed component referred to the base-salary for 40 hours and independently of the remuneration range; the variable component of the compensation was composed of financial gratifications for inducing quality and for the provision and retainment of workers; and towards permanent education.

The quality inducing gratification resulted in the monitoring and assessment of the monthly activities foreseen for the ESF (consultations, home visits, educational activities, workload, etc.) and of the performance of the whole team in reaching their half-yearly targets of quality, based on management contracts for healthcare, agreed-to between the municipality and the team.

Gratifications for inducing provision and retainment included additional pay for location, depending on the range in which the municipality was located; additional pay for permanence of, at least, two years in the same team, with the purpose of guaranteeing the bond of the professional with the user and with the community; and additional pay for special conditions, which consisted of a differential in compensation for remaining in certain regions, neighborhoods or locations within municipalities of difficult access, people in situation of vulnerability, high rates of violence and historically excluded populations. Finally, gratification for permanent education, corresponding to an incentive for the workers that took over as preceptors of residents and of tutors in specialization courses in Family Health, among others.

Despite the substance of the proposal for career, the existing culture of precarious contracting, limiting legal coverage of the labor contract, permitted doctors of the ESF to receive higher wages than those proposed by FESF-SUS. Managers, in turn, spent less with the teams, in the measure in which they did not pay all the social charges. This challenge of equating an attractive career for the worker without extrapolating the budget of the manager was a critical hitch for the expansion and maintenance of contracts of the municipalities with FESF-SUS.

\section{e) Assessment of the doctors in FESF-SUS}

The assessment had implications on the receiving of monthly and half-yearly gratifications and each municipality being jointly responsible. These occurred through the establishment of a healthcare management contract (CGC), in which the indicators, parameters and targets for the performance 
assessment of the workers were listed. The expectation was that the municipality would deepen the relationship with workers, managing their work process and giving priority to actions such as planning, programing the agenda, following-up and assessing indicators and agreed-upon targets.

One of the main consequences of the functional development assessment of FESF-SUS would be the approval or disapproval of the doctor during the experience period (90 days), as foreseen in the CLT, without mentioning the gratifications for the fulfillment of targets, functional progression of doctors and of dismissal of the professional from FESF-SUS in the case of low performance.

One of the challenges placed for this collaborative management between FESF-SUS and the contracting municipalities was qualifying professionals for the administration of the work and work process, in an articulated manner without losing sight of the need for guaranteeing a sole command of the municipality in its territory.

\section{f) Functional progression}

The functional and financial progression of FESF-SUS doctors would occur through the progression by merit and additional pay for educational degrees (Andrade, 2011). In the case of progression by merit, 2 years of effective exercise in the position/function; a minimum of 12 months in the job; minimum grade established in the assessment process for functional development; inexistence of leave of absence for over 90 days, in the last 12 months, with exception to maternity leave; not having been removed from exercising the activities of the position/function, with exception to hypothesis of appropriate use, substitution and re-adaptations foreseen. In this matter, FESF-SUS would establish for each year the percentage of doctors who would have the right to this progression, observing the limiting range of a minimum of $20 \%$ and maximum of $60 \%$.

Progression due to educational degrees would consist of a financial evolution of the compensation throughout the functional period of the doctor, incurring over the initial standard salary. This progression had the objective of stimulating qualification and permanent education of the workers (Andrade, 2011).

\section{g) Retirement}

Doctors hired by the CLT regimen in public administration, thus as civil servants of FESF-SUS, would be outside the public social security, having to contribute to the General Social Security System, to guarantee their rights to retirement benefits in accordance with the rules valid for the workers of all other sectors of the economy. It is an issue highly debated by CES as one of the possible cause for the loss of professionals hired by a private-law foundation, such as FESF-SUS.

\section{DISCUSSION}

The FESF-SUS proposal contemplated the construction of a career for the SUS, a problem mentioned in the origin of the SUS and contemplated in the Final Report of the Brazilian Health Sector Reform Commission (National Commission for Health Sector Reform [CNRS], 1986).However, to undertake this agenda as a project for the expansion of the ESF, through the attempt of promoting and retaining professionals based on an inter-municipal career, fostered controversies, intense debates and tensions 
in the legal, legislative and executive fields, both in the municipal and state spheres and, according to the criteria proposed by Kingdon (2003), may be pointed out as visible governmental actors in the political scenario.

The proposal articulated two big questions for today's primary care: provision and retainment of doctors in remote areas, in which prior experiences were not undertaken as an issue of the State, but were temporary programs, such as PITS. Despite the provision and retainment of doctors being issues that give the shape to the problematic of the medical workforce, gradually, the idea related to the provision was upstaged by the retainment of doctors. An example of this was the emergence of national programs, with the purpose of providing doctors to remote areas (CNRS, 1986; Inter-ministerial Ordinance 1369, 2013) supported by the managers (Cremesp, 2013a, 2013b). Internationally, studies demonstrate that the programs for the provision of doctors are accompanied by inducing measures for the installation of doctors in public-health gaps (Oliveira et al., 2015; Santos et al., 2015; Wilson et al., 2009).

The results of the study reveal that the problem of retaining and providing doctors in Bahia is similar to other states of Brazil and also to other countries (F. E. Campos, Machado, \& Girardi, 2009). Moreover, the study demonstrates that improvement in the working conditions would be fundamental for retaining health professionals, especially doctors. Results from other researches corroborate working conditions as being a determining action for the attraction of doctors in areas of difficult access (N. M. Silveira \& Rodrigues, 2012). In municipalities where management invested in addressing this matter there was a retainment of these professionals, as occurred in Aracaju, Florianópolis, Belo Horizonte and Vitória (Mendonça, Martins, Giovanella, \& Escorel, 2010).

In the case of FESF-SUS, the scope of the career depended on adhesion of the municipalities to the proposal, occurring via management contracts. In order to be attractive to doctors, it was necessary for municipalities of different sizes and socio-political and economic conditions to adhere to the foundation. After all, the proposed mobility of the doctors in their careers implied in a range of choices.

Nevertheless, the contracting period among the municipalities and FESF-SUS was characterized by the search for renegotiations of the contractual values by the municipalities, implying in the lowering of the salary levels of various professional categories, even before beginning the services (Ceccim et al., 2016).

Also, some municipalities, despite having participated of the debate on the design of the foundation, did not adhere to the contracting with FESF-SUS in view of uncertainties in relation to the incentives foreseen to be provided by MS and by Sesab. After all, the contracting regimen through the CLD would bring a new set of financial commitments to municipalities already facing fiscal difficulties. Furthermore, the lack of a unanimous position of the Court of Auditors of the Municipalities (TCM) and of the Court of Auditors of the State (TCE) on the incidence, or not, of the Fiscal Responsibility Law on the contracts signed with FESF-SUS.

The insecurity resulting from these factors hindered the adhesion of an important part of municipal managers after the establishment of the foundation, in other words, at the moment of entering into contracts. The financial feasibility of FESF-SUS was being questioned, in the measure in which the number of foreseen contracts was not made effective.

In addition to this set of difficulties there was the development of programs for the provision of medical professionals for primary healthcare, accompanied by federal financial incentives, which translated into weakening the debate on a state career led by FESF-SUS in Bahia, considering that the latter did not forgo the participation of the municipalities in this financing. The potential of the FESF- 
SUS experience as a model for a National Human Resource Policy came against prioritizing emergency provision consubstantiated in the formulation of Law 12.871 (2013), which created the PMM.

A review study on the PMM pointed out that there was the fulfillment of 14,462 vacancies in 3,785 municipalities, for a demand by manager of around 15,460 vacancies for doctors. Further, as from the PMM, the family health coverage had an expressive increase, mainly in the poorer regions, such as the North of Brazil, which had the provision of 4.9 doctors, per municipality, on average (Kemper, Mendonça, \& Souza, 2016).

Another review study discussed that despite recognizing that there was a reduction in the shortage of doctors in Brazil, as a whole, and decrease in the shortage of doctors in regions with high rates of need for doctors, such as the North and Northeast of Brazil, some systematized studies demonstrate evidence of substitution of existing teams, with effects on the provision and retainment. This same study reinforces prior results, which demonstrate low adhesion of doctors to units with tougher working conditions (Medina \& Almeida, 2018).

Scheffer (2015b), in a study on the demography of doctors, registers the insertion of a substantive number of doctors in Brazil (around 100,000 doctors). Nevertheless, the inclusion of these professionals did not alter significantly inequality in the distribution of these professionals, once they remained in their same locations.

Although federal programs do not deal only with the provision of doctors, the PMM is placed as a central matter and addressing the matter of retainment is not part of the program. To the contrary, the adoption of payment of the doctors through grants leaves open the issue of instability, due to the fact that there are labor rights are not guaranteed. However, despite the challenges of the improvement in working conditions having been left aside by the PMM, information from literature demonstrates that this initiative permitted the fulfillment of public health gaps, providing around 15,000 medical professionals throughout the country (G. W. S. Campos, 2015; Oliveira et al., 2015).

Considering the historical need for the provision and retainment of doctors in the ESF, mainly in zones of difficult access and in urban outskirts, the analysis on the implementation of the FESFSUS proposal in Bahia is suggested, once it may reveal elements on its improvement, its fragilities and, also, contexts that deserve to be analyzed by the scholars and managers of Collective Health, in order to strengthen the SUS.

Literature points out that some states promoted investment in the administration of the work and that, for this reason, granted the retainment of the health professionals - mainly doctors (N. M. Silveira \& Rodrigues, 2012). However it is not possible to observe an institutionalized policy having on its agenda the solution to overcome this problem.

\section{FINAL CONSIDERATIONS}

This article analyzed the Policy for the Provision and Retainment of Doctors developed by FESF-SUS, identifying relevant aspects and contents of the drawn-up proposal. In this respect, the singularity and originality should be highlighted regarding the inter-municipal career design.

In the negotiation process to render feasible the proposal, the legislative movement that was triggered in the state of Bahia calls attention once there were the approvals of laws for authorization of the establishment of the foundation in 100 municipal chambers. Despite this movement, only 69 municipalities presented the necessary documentation, in notary offices, to legally establish and inter- 
federate foundation, the FESF-SUS. The other existing inter-municipal proposals in this context were consortia, focused on the contracting and not in the formation of a career.

The FESF-SUS proposal foresaw the organization of elements of information system management, work administration and work process administration, as well as the management of contracts, historically presented as limitation of municipal managers. Practical examples of these challenges are in the complexity of the compensation of doctors, in view of the combined gratifications, additional pay and differences in the ranges among the municipalities.

It is observed that the same strategic and innovative elements proposed by FESF-SUS in the field of work management also correspond to their main challenges, once the operationalization depends on variables related both to changes in the outdated and rigid culture of the administration of workers, low qualification of the administrators and workers for conducting new strategies for the provision and retainment, and the FESF-SUS career, as well as in outstanding issues in the legal field, and the crucial financial limitations that befall the municipalities.

The feasibility of the career of doctors, through FESF-SUS, for example, assumes that the municipalities with greater difficulties in the provision and retainment would have to depend on subsidies from incentives of the MS and Sesab, However, the advent of programs for valorization of primary care and of the PPM, with grants for doctors funded by the MS, became more attractive for the administrators, once they would not burden their coffers and, also for the workers, once when receiving the grants they would be exempt of income tax deductions, for example.

The reduction in management contracts of the municipalities with the FESF-SUS was notorious as of the creation of the Provab and of the PPM. An example of this is that, presently, there are no more FESF-SUS contracts related to the medical career for the ESF in the proposed models in the creation of the foundation. On the other hand, in the face of the scale of the federal programs for provision, FESF-SUS opted to position itself as collaborator, encompassing strategies of formation and provision in partnership with the MS, such as Multidisciplinary Health Residency in Family Health (RMSF) and Medical Residency in Family and Community Medicine (RMMFC), apart from becoming a supervisory institution of the Provab in 7 municipalities of Bahia, in 2016.

Accordingly, the issue of provision and retainment of professionals in the ESF requires profound dialogue between the administrators of the three levels of attention. After all, these are structural and institutional problems of the SUS that are not possible to simply overcome through isolated programs or strategies.

Furthermore, the debate on stable sources of financing (for municipalities) and investments for enabling the expansion of the offer of actions and services should consider socio-economic inequalities and the peculiarities of each municipality, resulting from historical and structural characteristics and their trajectories in health policies.

The path followed by the municipalities, states and the MS, in the attempt of guaranteeing the universal access of users has produced new proposals and countless challenges. On observing the experiences debated herein and the results obtained with each of the strategies for providing and retaining doctors, it is now necessary to advance also in relation to improving working conditions and on the development of mechanisms capable of promoting and strengthening labor relations with the SUS. 


\section{REFERENCES}

Andrade, L. (2011). A FE no SUS: Fundação Estatal como proposta de gestão do trabalho para a Estratégia Saúde da Família na Bahia. Rio de Janeiro, RJ: Ed. Fiocruz.

Andrade, L., Teixeira, M., \& Machado, C. V. (2012). Gestão do trabalho na Estratégia Saúde da Família: a proposta da Fundação Estatal Saúde da Família da Bahia. Revista Divulgação em Saúde para Debate, 47, 65-76.

Bardin, L. (1977). Análise de conteúdo. Lisboa, Portugal: Ed. 70.

Campos, C. V. A., \& Malik, A. M. (2008). Satisfação no trabalho e rotatividade dos médicos do Programa de Saúde da Família. Revista de Administração Pública, 42(2), 347-368.

Campos, F. E., Machado, M. H., \& Girardi, S. N. (2009). A fixação de profissionais de saúde em regiões de necessidades. Revista Divulgação em Saúde para Debate, 44, 13-24.

Campos, G. W. S. (2015). Mais médicos e a construção de uma política de pessoal para a atenção básica no Sistema Único de Saúde (SUS). Interface - Comunicação, Saúde, Educação, 19(54), 641-642.

Carvalho, F. C. (2014). A consolidação do Programa Mais Médicos na opinião pública e na cobertura jornalística. In Anais do 15o Congresso de Ciências da Comunicação na Região Sul. Florianópolis, SC. Retrieved from http://www.portalintercom.org.br/ anais/sul2014/resumos/R40-0325-1.pdf

Carvalho, M. S., \& Sousa, M. F. (2013). Como o Brasil tem enfrentado o tema provimento de médicos? Interface - Comunicação, Saúde, Educação, 17(47), 913-926.

Ceccim, R. B., Kreutz, J. A., Campos, J. D. P., Culau, F. S., Wottrich, L. A. F., \& Kessler, L. L. (Orgs.). (2016). In-formes da Atenção Básica: aprendizados de intensidade por círculos em rede. Porto Alegre, RS: Rede UNIDA.

Centro Brasileiro de Estudos de Saúde. (2013, 26 de julho). O SUS precisa de Mais Médicos e de muito mais! Retrieved from http://cebes.org.br/2013/07/osus-precisa-de-mais-medicos-e-de-muito-mais/
Collar, J. M., Almeida, J. B., Neto, Ferla, A. A. (2015). Formulação e impacto do Programa Mais Médicos na atenção e cuidado em saúde: contribuições iniciais e análise comparativa. Saúde em Redes, 1(2), 43-56.

Comissão Nacional de Reforma Sanitária. (1986). Secretaria Técnica da Comissão Nacional da Reforma Sanitária. Rio de Janeiro, RJ: Author.

Conselho Nacional de Secretários de Saúde. (2004). Estruturação da área de recursos humanos nas Secretarias de Saúde dos Estados e do Distrito Federal. Brasília, DF: Autor.

Conselho Regional de Medicina do Estado de São Paulo. (2013a). Características gerais da população de médicos. São Paulo, SP: Author.

Conselho Regional de Medicina do Estado de São Paulo. (2013b). Demografia médica no Brasil: cenário e indicadores de distribuição. São Paulo, SP: Autor.

Escorel, S., Giovanella, L., Mendonça, M. H. M., \& Senna, M. C. M. (2007). O Programa de Saúde da Família e a construção de um novo modelo para a atenção básica no Brasil. Revista Panamericana de Salud Pública, 21(2), 164-176.

Estado da Bahia. (n.d.). Diretoria de Atenção Básica. Retrieved from http://www.saude.ba.gov.br/dab

Fundação Estatal Saúde da Família. (n.d.). A Fundação. Retrieved from http://www.fesfsus.ba.gov. br/a-fundacao/quem-somos

Girardi, S. N., Carvalho, C. L., Araújo, J. F., Farah, J. M., Wan der Maas, L., Campos, L. A. B.. (2011). Índice de escassez de médicos no Brasil: estudo exploratório no âmbito da atenção primária. In C. R. Pierantoni, M. R. Dal Poz, \& T. França (Orgs.), $O$ trabalho em saúde: abordagens quantitativas $e$ qualitativas (pp. 171-86). Rio de Janeiro, RJ: Cepesc, IMS/UERJ, \& Observa RH.

Kemper, E. S., Mendonça, A. V. M., \& Souza, M. F. (2016). Programa Mais Médicos: panorama da produção científica. Ciência \& Saúde Coletiva, 21(9), 2785-2796.

Kingdon, J. W. (2003). Agendas, alternatives and public policies (2a ed.). New York, NY: Longman. 
Lei n. 12.871, de 22 de outubro de 2013. (2013). Institui o Programa Mais Médicos, altera as Leis n. 8.745, de 9 de dezembro de 1993, e n. 6.932, de 7 de julho de 1981, e dá outras providências. Brasília, DF.

Machado, M. H. (1997). (Coord.). Os médicos no Brasil: um retrato da realidade (20a ed.). Rio de Janeiro, RJ: Ed. Fiocruz.

Medina, M. G., \& Almeida, P. F. (2018). Panorama Mais Médicos no Brasil: panorama da produção científica (Série Técnica Saúde Universal e Programa Mais Médicos - Working Paper n. 2). Brasilia, DF: Organização Pan Americana de Saúde.

Mendonça, M. H. M., Martins, M. I. C., Giovanella, L., \& Escorel, S. (2010). Desafios para gestão do trabalho a partir de experiências exitosas de expansão da Estratégia de Saúde da Família. Ciência \& Saúde Coletiva, 5(15), 2355-2365.

Oliveira, F. P., Vanni, T., Pinto, H. A., Santos, J. T. R., Figueiredo, A. M., Araújo, S. Q. ... Cyrino, E. G. (2015). Mais médicos: um programa brasileiro em uma perspectiva internacional. Interface Comunicação, Saúde, Educação, 19(54), 623-634.

Perpetuo, I. H. O, De Oliveira, A. C., Ribeiro, M. M., Rodrigues, R. B. (2009). A categoria profissional dos médicos: fatores condicionantes da sua atração e fixação na Atenção Primária à Saúde em Minas Gerais. Belo Horizonte: Observatório de Recursos Humanos em Saúde do Nig. One / UFMG.

Portaria Interministerial n. 1.369, de 8 de julho de 2013. (2013). Dispõe sobre a implementação do
Projeto Mais Médicos para o Brasil. Brasília, DF: Ministério da Saúde \& Ministério da Educação.

Rourke, J. W. (2010). Recommendations to improve retention of rural and remote health workers: important for all countries. Rural Remote Health, 10(4), 1-4.

Santos, L. M. P., Costa, A. M., \& Girardi, S. N. (2015). Programa Mais Médicos: uma ação efetiva para reduzir iniquidades em saúde. Ciência \& Saúde Coletiva, 20(11), 3547-3552.

Scheffer, M. (2015a). Programa Mais Médicos: em busca de respostas satisfatórias. Interface Comunicação, Saúde, Educação, 19(54), 637-640.

Scheffer, M. (Coord.). (2015b). Demografia médica no Brasil 2015. São Paulo, SP: Conselho Regional de Medicina do Estado de São Paulo \& Conselho Federal de Medicina.

Silveira, N. M., \& Rodrigues, P. H. A. (2012). Fatores críticos para a fixação do médico na Estratégia Saúde da Família. Physis, 22(4), 1293-1311.

Silveira, R. P., \& Pinheiro, R. (2014). Entendendo a necessidade de médicos no interior da Amazônia - Brasil. Revista Brasileira de Educação Médica, 38(4), 451-459.

Wilson, N. W., Couper, I. D., Vries, E., Reid, S., Fish, T., Marais, B. J. (2009). A critical review of interventions to redress the inequitable distribution of healthcare professionals to rural and remote areas. Rural Remote Health, 9(2), 1-21.

Yin, R. K. (2001). Estudo de caso: planejamento e métodos. Porto Alegre, RS: Bookman. 


\section{Laíse Rezende de Andrade}

https://orcid.org/0000-0002-1149-7636

$\mathrm{PhD}$ student in Public Health at the Institute of Collective Health of the Federal University of Bahia (ISC/UFBA).

E-mail: laiseandrade@hotmail.com

\section{Isabela Cardoso de Matos Pinto}

https://orcid.org/0000-0002-1636-2909

Associate Professor at the Institute of Collective Health of the Federal University of Bahia (ISC/UFBA).

E-mail: isabelacmp@gmail.com

\section{Catharina Leite Matos Soares}

ID

https://orcid.org/0000-0002-8131-4831

Adjunct Professor at the Institute of Collective Health of the Federal University of Bahia (ISC/UFBA).

E-mail: catharinamatos@gmail.com

\section{Vinício Oliveira da Silva}

https://orcid.org/0000-0003-4149-1777

Professor at the Federal University of Paraná (UFPR). E-mail: viniciooliveira@ufpr.br 